\title{
Studies on Amyloodinium Infestation in European Seabass (Dicentrarchuslabrax.) Fishes with Special Reference for Treatment.
}

\author{
Samar Saad Seoud ${ }^{1, *}$, Viola H. Zaki ${ }^{1}$, Gamal E. Ahmed ${ }^{2}$, \\ Nevien K. Abd El-Khalek ${ }^{1}$ \\ ${ }^{1}$ Department of Internal Medicine, Infectious and Fish Diseases, Faculty of Veterinary Medicine, Mansoura \\ University, Mansoura 35516, Egypt. \\ ${ }^{2}$ Vice Dean for Education and Student Affairs, Faculty of Veterinary Medicine, Zagazig University, Zagazig \\ 44511, Egypt.
}

\begin{abstract}
Amyloodinium ocellatum, adino flagellate which causes one of the most serious diseases of warm water marine aquaculture. The parasite produces a powdery or velvety appearance on infected fish, and the resulting disease is commonly referred to as "marine velvet," velvet disease, or Amyloodiniosis. The organism is a dinoflagellate ectoparasite and has been reported in a wide range of marine and estuarine fish. It is one of a very few organisms that can infect both teleosts and elasmobranchs (Alvarez-Pellitero, 2008). This makes it a concern for public aquaria. This ectoparasite can be found on gills and skin (body and fins) of host fish. It can cause devastating disease and mortality because the organism is able to reproduce quickly when fish are crowded, especially in closed systems. This parasite has a broad host and geographic range, causing fish mortalities in tropical and temperate environments. Rapid spread of the parasite and high mortality are common in cultured fish if the organism is not recognized and treated early in the course of an outbreak. One of the most important of theectoparasitic protozoaisIn this respect, the present study was aimed to investigate the occurrence of Amyloodiniosisamong cultured European seabass (Dicentrarchuslabrax L.; Moronidae; Perciformes) fishes. This work was carried out on 1065 European seabass fishes of different life stages (546 fry-222 fingerling and 78 adults) which were collected in different seasons of the year. Cultured fish were collected from different marine farms in Egypt during the period from April 2015 to April 2016 and subjected to full clinical parasitological and histopathological examination studying the environmental stressors surrounding examined fish and their association withA.ocellatum infestation Study the ecological factors affects Amyloodiniosis. As well as examining the antiseptic activity of hydrogen peroxide against the ectoparasitic protozoanA.ocellatumas a trial for treatment.
\end{abstract}

Keywords: Amyloodiniumocellatum, European Seabass Fishes, Infestation, Treatment, Dicentrarchuslabrax L., Ectoparasitic Protozoa, Histopathological, Parasitological, Egypt.

\section{Introduction}

Amyloodiniumocellatum(an ectoparasiticdinoflagellate)is one of the most important pathogenic parasites affecting the culture of marine and brackish water fishThe parasite produces a powdery or velvety appearance on infected fish, and the resulting disease is commonly referred to as "marine velvet," velvet disease, or amyloodiniosis. (Noga and Levy 2006). Amyloodiniumocellatumis an extremely prolific and devastating ectoparasiticdinoflagellate of fish both and brackish marine water environments. The organism is aldinoflagellate ectoparasite and has been reported in a wide range of teleosts and elasmobranchs (Alvarez-Pellitero, 2008). European Seabass (Dicentrarchuslabrax L.; Moronidae; Perciformes) is a marine fish of great economic importance particularly in Mediterranean aquaculture (Zorilla et al., 2003a). European seabass represents a major fisheries and aquaculture species in the Mediterranean, the European Atlantic coasts and North Africa (Kuhl et al., 2010). High mortality and morbidity was recorded amongdifferiental stages of cultured European seabass (Dicentrarchuslabrax) caused byAmyloodinium ocellatum.

Thus, the research work carried out in this thesis depends on three main branches:

A- Provide diagnostic procedures of Amyloodiniosis applicable under field conditions.

B- Explain the histopathological changes altered by Amyloodiniosis.

C- Statistical analysis was made with the computer program (Statistical Package for Social Sciences) SPSS.

Differences among groups were assessed by means of analysis of variance (ANOVA). Subsequently, significance of differences between values was tested with the LSD post-hoc test (least significant difference test) to detect particular differences between groups. Values are represented as mean \pm standard error (mean \pm S.E.M). Significance indicated in figures and tables by an asterisk $(*)$ was taken as $p<0.05$.

Statistical analysis on data that that obtained from:

1-Investigate the occurrence of Amyloodiniosis in European Seabass Dicentrarchuslabrax.

2-Study the ecological factors affects Amyloodiniosis.

3-Treatement measures using for Amyloodiniosis. 


\section{Materials And Methods}

\section{Materials}

1- Fish used for natural examination

A total number of 1065 European Sea bass (Dicentrarchuslabrax) were obtained from different marine fish farms in Egypt and examined for Amyloodinium ocellatum.

\section{2- Fish used for experimental examination}

A total number of $120 \mathrm{D}$. labrax fingerlings were obtained and acclimatized in fiberglass aquaria for conduction of treatment trial of Amyloodinium ocellatum infection.

\section{3- Aquaria and concrete pond}

A- Dicentrarchuslabrax used for natural examinations, were held in Glass aquaria $(40 \times 50 \times 60 \mathrm{~cm})$.

$B$ - Dicentrarchuslabrax fingerlings used for conduction of treatment trial of Amyloodinium ocellatum infection, were held in fiberglass tanks $(1000 \mathrm{~L})$.

$C$ - The used fiberglass tanks and Glass aquaria were supplied with fresh seawater and aerated through air blower. Natural seawater should be with water temperature ranged at $(25 \pm 3$ OC), Dissolved Oxygen D.O $5 \pm 3 \mathrm{mg} / \mathrm{l}, \mathrm{pH} 7.4-8.8$, salinity at $12 \pm 3 \%$ salinity and supplied with air systems.

\section{Methods}

\section{1- Fish sampling}

European D. labrax were sampled from April 2015 to April 2016. Freshly dead or morbid fish were taken and kept in ice boxes and transported as soon as possible to Fish Diseases Laboratory.

\section{2- Water sampling}

They were collected in glass or plastic and transported to the laboratory in insulated coolers and examined within $(24-48 \mathrm{~h})$. They include water temperature, dissolved oxygen, $\mathrm{pH}$, ammonia(NH3/NH $\left.4^{+}\right) \& s a l i n i t y$, Water temperature, dissolved oxygen and salinity were measured at collection sites. All water quality parameters were analyzed according to (APHA 2005).

\section{3- Laboratory diagnosis of Amyloodiniosis}

A) -Clinical investigation and Post Mortem (PM) examination: -

It was performed according to Noga, (2010).Fish samples with various clinical symptoms like excessive mucous, erosions on the fins, deformity on vertebral column, pale to brownish gills were brought to the laboratory.

B)- Parasitological examination.

1)-Macroscopic examination.

Skin surface, fins and gills were examined by naked eyes and with the help of dissecting microscope for any attached parasites, lesions or external changes.

2)- Microscopic examinations

Direct wet mount techniques (skin scrapping: taking smear mucus cells and scales) and gill biobsy or gill clip (at which a gill filament is removed for microscopic diagnosis).

\section{4- Histopathological examination}

Samples (skin, fin and gills) were carefully removed from examinedDicentrarchuslabrax then fixed in neutral formalin, dehydrate in ascending grades of alcohol and clear in xylene. The fixed tissues were embedded in paraffin wax and sections of five microns were caught by using Euromex Holland microtome. Sections were stained according to Harris Haematoxylin and Eosin method (Agius and Roberts 2003). Then sections were examined and photo taken microscopically.

\section{5- Treatment trials for Amyloodiniosis}

A- Supplemented Antiseptic and Route and dose of administration:

The selected antiseptic was hydrogen peroxide $\mathrm{H}_{2} \mathrm{O}_{2} 20 \%$. It was added within a dose and duration according to (Montgomery - Brock et al., 2001).

\section{B- Bath route}

Additional aeration may also be required for bath treatments. It was added at $100 \mathrm{ppm}, 200 \mathrm{ppm}$ in plastic container 10 liter and treat for a duration of exposure 30 minutes for Amyloodiniosis. Re -treat after 6 days. 


\section{C- Experimental design}

A total of 120 Dicentrarchuslabrax fingerlings were divided into four groups of 30 each and distributed equally in fiberglass tanks size $(1000 \mathrm{~L})$. Each treatment was performed in triplicates. Four groups of D. labrax, the first is apparently health as control(G1) and the second was the clinically infested group (G2). The third infested was immersed with $\mathrm{H}_{2} \mathrm{O}_{2}$ at $100 \mathrm{ppm} / \mathrm{L}(\mathrm{G} 3)$ and the fourth infested immersed with $\mathrm{H}_{2} \mathrm{O}_{2}$ at 200ppm/L( G4).It was added at 100ppm,200ppmas water bath in 10 liter plastic container for 30 minutesthen returned to rearing $\operatorname{tank}(1000 \mathrm{~L})$. The experiment was inspected daily for 14 days and the clinical signs and mortality was recorded. The data on mean mortality intensity of infection and prevalence rate were recorded in first week \&second week. The mean of length \& weight of used fishes were reported in table(1) \&fig. $1 \& 2$.

Table 1. Comparison of Length and Weight (gm) among treated groups No. (\%) after (30 min.) treatment

\begin{tabular}{|l|l|l|}
\hline & Length $(\mathbf{C m})$ & Weight $(\mathbf{g m})$ \\
\hline Control -Ve(G1) & $6.98 \pm 0.31^{\mathbf{a}}$ & $7.43 \pm 0.19^{\mathbf{a}}$ \\
\hline Control +Ve(G2) & $7.68 \pm 0.58^{\mathbf{a}}$ & $7.77 \pm 0.28^{\mathbf{a}}$ \\
\hline $\mathbf{1 0 0} \mathbf{~ p p m ( G 3 )}$ & $7.31 \pm 0.45^{\mathbf{a}}$ & $5.13 \pm 0.47^{\mathbf{a}}$ \\
\hline $\mathbf{2 0 0} \mathbf{~ p p m ~ ( G 4 ) ~}$ & $8.05 \pm 0.68^{\mathbf{a}}$ & $6.33 \pm 0.39^{\mathbf{a}}$ \\
\hline
\end{tabular}

Means within the same column carrying different superscripts are sig. different at $\mathrm{P}<0.05$ based on Tukey's Honestly Significant Difference (Tukey's HSD). There was no significance difference between the length and weight in treated and non-treated groups.

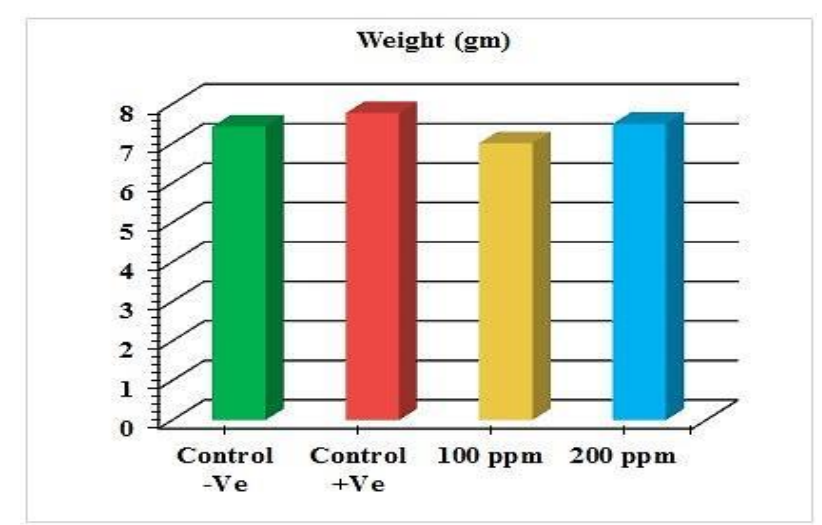

Fig. 1 Comparison of Length among treated groups No. (\%) after (30 min.) treatment

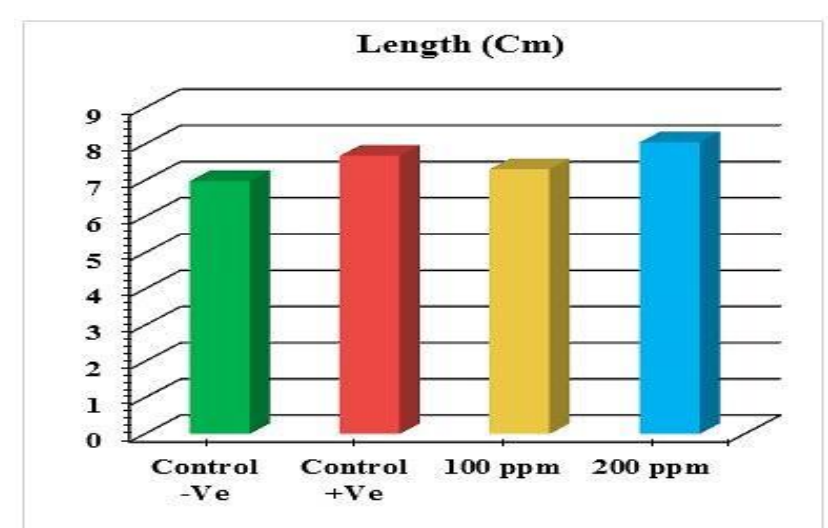

Fig. 2 Comparison of Weight (gm) among treated groups after (30 min.) treatment

\section{D- Statistical analysis}

Statistical analysis was made on all data that present in this study with the computer program (Statistical Package for Social Sciences) SPSS. Differences among groups were assessed by means of analysis of variance (ANOVA). Subsequently, significance of differences between values was tested with the LSD post-hoc test (least significant difference test) to detect particular differences between groups. Values are represented as mean \pm standard error (mean \pm S.E.M). Significance indicated in figures and tables by an asterisk $(*)$ was taken as $p<0.05$. 


\section{1- Clinical signs and post mortem changes}

\section{Results}

The infested European seabassDicentrarchuslabrax with Amyloodiniumocellatum appeared distressed, emaciated, and anorexic and showed flashing behavior. Also, there were gasping of air rapid gill movement and lying on the bottom. There was rapid and mass death of fish. Also, grosslyfocal erosion areas were seen on the operculum andcaudaltail.deformity in vertebral column. The affected skin showed friable skin (velvet like appearance), , darkened, excessive mucous secretions, Also, sometimes grossly focal erosion caudal tail. Internally the infested fish, showed pale liver enlarged spleen and fatty position on gastro intestinal tract.

\section{2- Parasitological examination}

\section{A) - Morphological description:-}

Microscopic examination of skin and gills scrapings of examined D. labrax showed, round to oval small dark brown mucoidAmyoodiniumocellatumstage measured up to $150 \mu \mathrm{m}$. Different developmental life stages of Amyloodiniumocellatumwere seen in the gill and skin tissues as the two main inhabitant organs. The first stage was trophonts with its root - like structure (Rhizoids). They showed distended appearance with the presence of feeding stage trophonts dark brown color lodged between the gill filaments. Also, observed between the skin and fin surface the rhizoids root-like structure (that penetrates deep in to epithelium causing substantial damage to tissue at the attachment site) of the attached organelle was sometimes visible as in figures (Figure 3, 7, 8 and 10). The second was tomont stage; trophont stage feeds for several days, detaches, retracts its rhizoids and becomes tomont. Tomonts (reproductive stage) in division were occasionally observed as in figures $3,4,5,6,9,10,11 \&$ a special picture of advanced stage of division of tomont stage in figure (12).

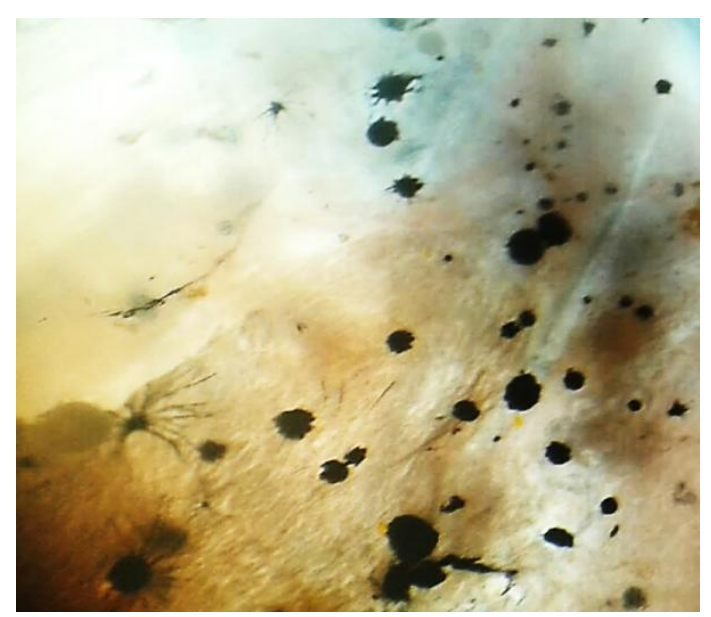

Fig. 3 Showing fresh mount of gill tissue heavy infested with Amyloodiniumocellatum (trophont stage with rhizoid root) and Tomont stage (first division.)

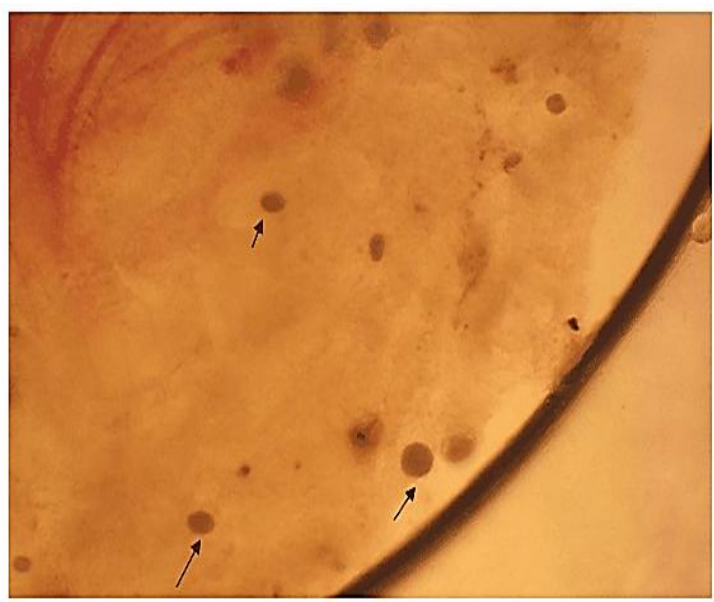

Fig. 4 Showing fresh mount of gill tissue slightly infested with Amyloodiniumocellatum( trophont stage).division. 


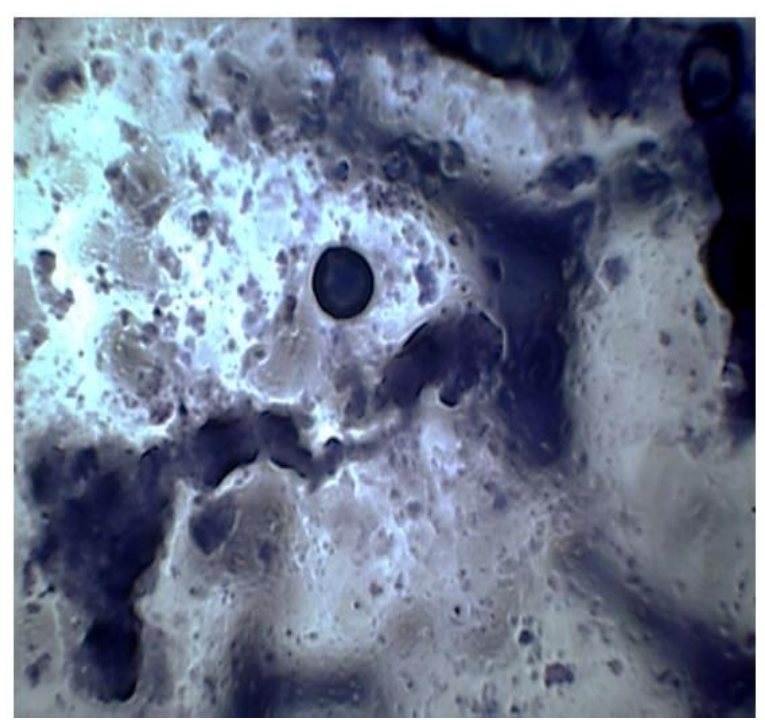

Fig. 5 Showing stained gill tissue infested with Amyloodiniumocellatum(trophont stage)Geimsa X100.

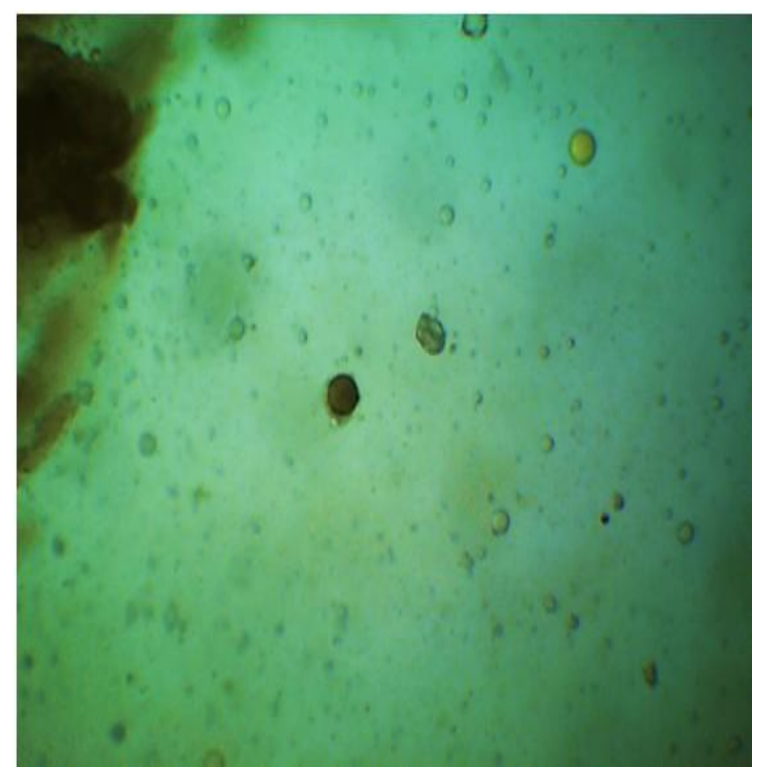

Fig. 6 Showing fresh mount of gill tissue slightly infested with Amyloodiniumocellatum( tomont stage).

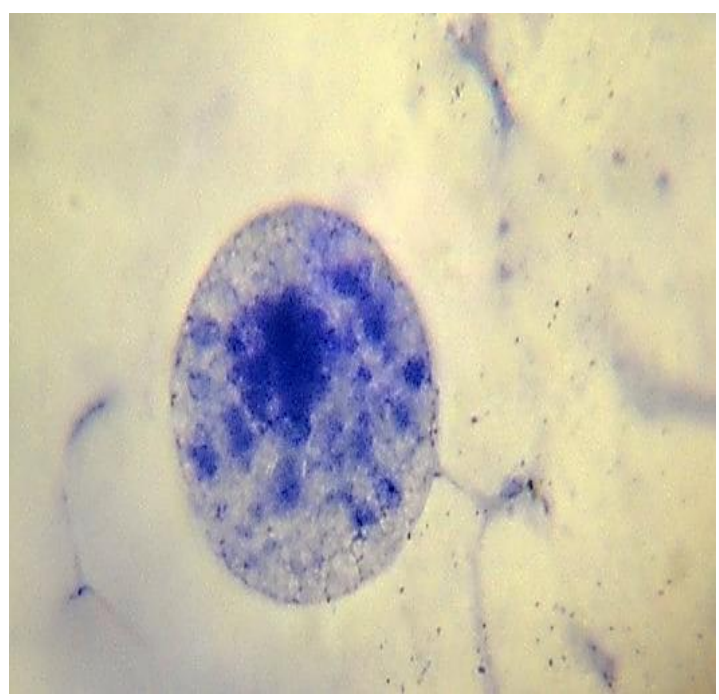

Fig. 7 Showing stained fresh mount of skin infested with Amyloodinium ocellatum (Trophont stage) Geimsa $\mathrm{X} 400$. 


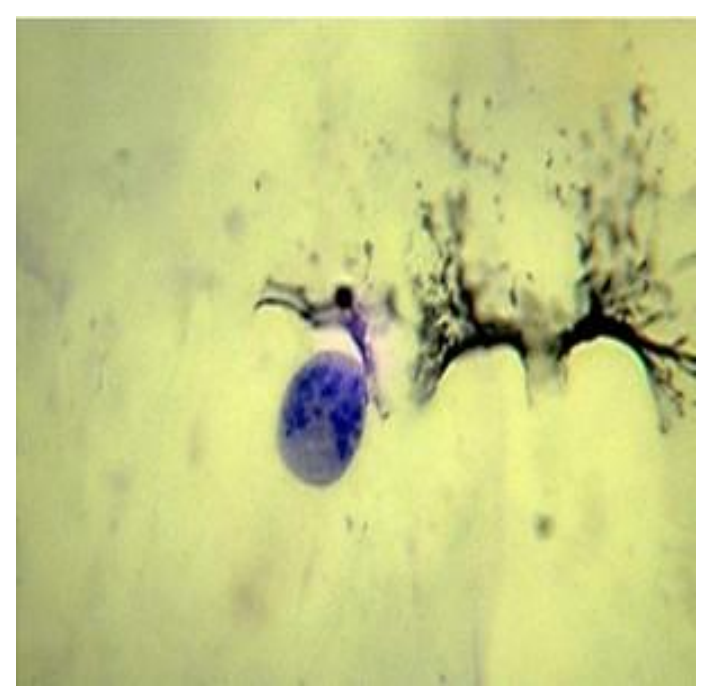

Fig. 8 Showing stained fresh mount of skin infested with Amyloodiniumocellatum (Trophont stage) Geimsa X100.

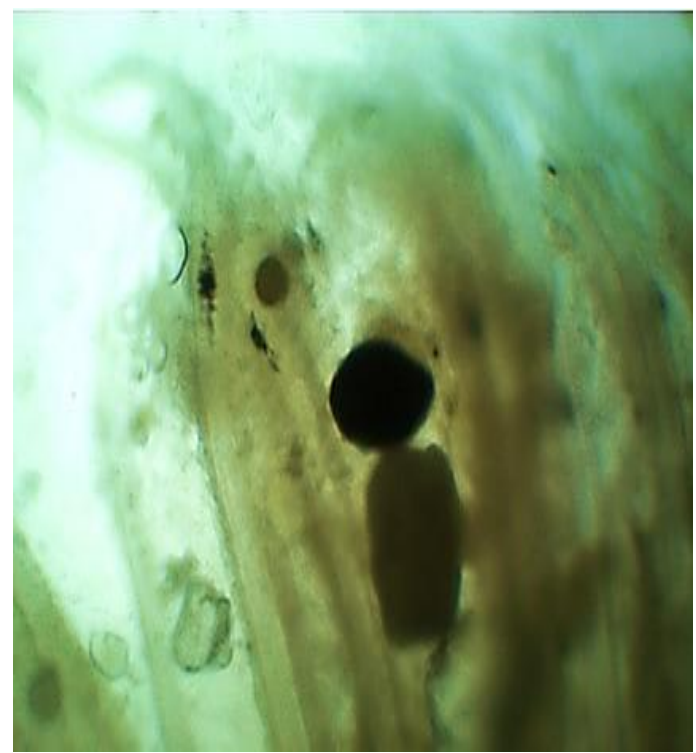

Fig. 9 Showing gill tissue infested withAmyloodiniumocellatum(reproductive stage tomont)

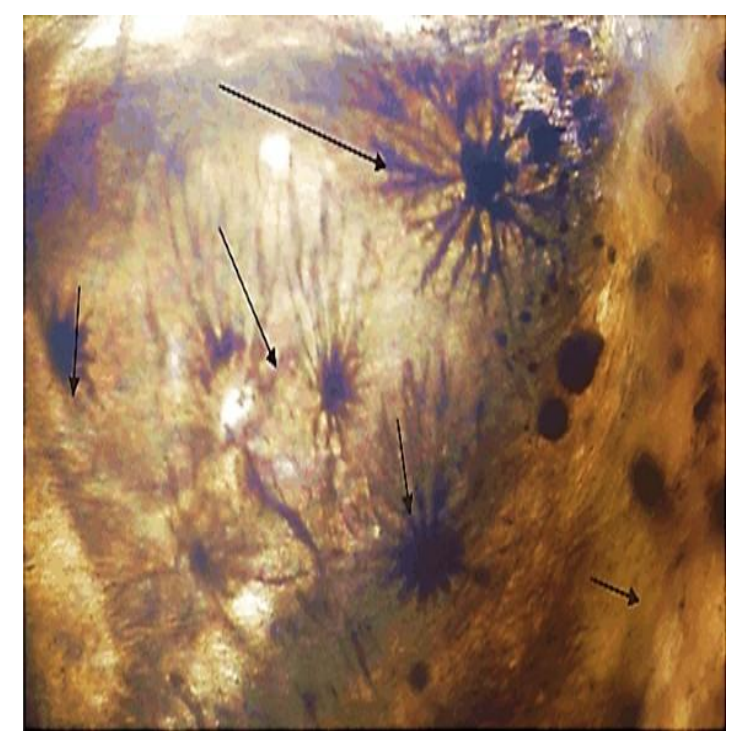

Fig. 10 Showing fresh mount of gill tissue infested with Amyloodiniumocellatum (trophont stage with rhizoid root- like structure). 


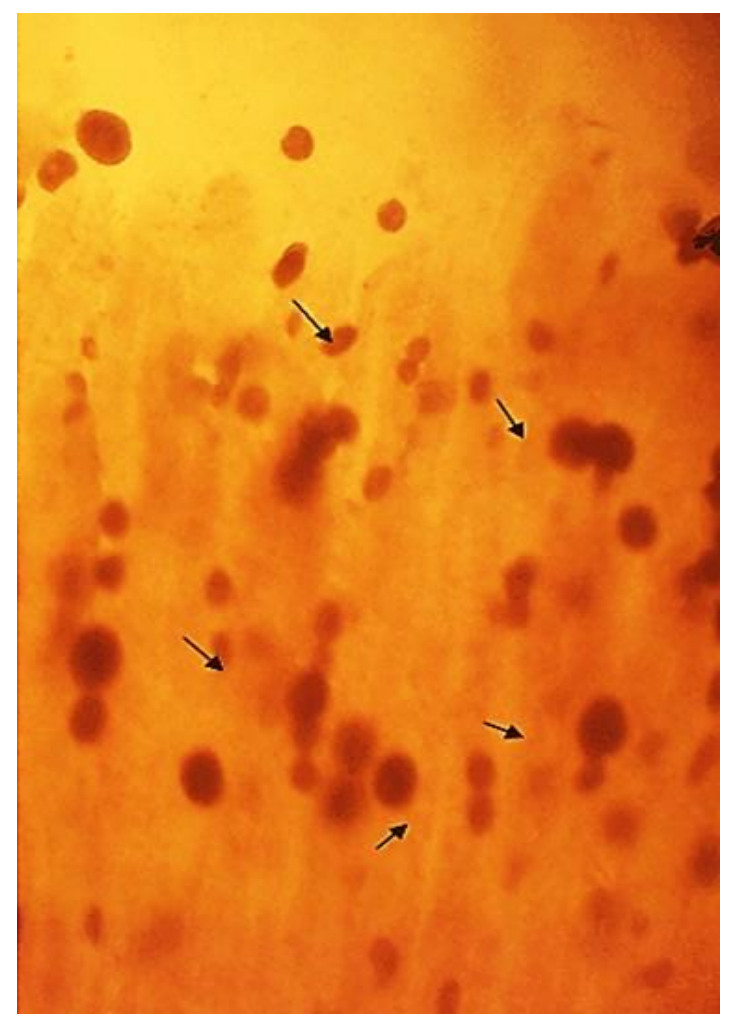

Fig. 11 Showing fresh mount of gill tissue infested heavily with Amyloodiniumocellatum (trophont and tomont stage first division(Arrowheads).

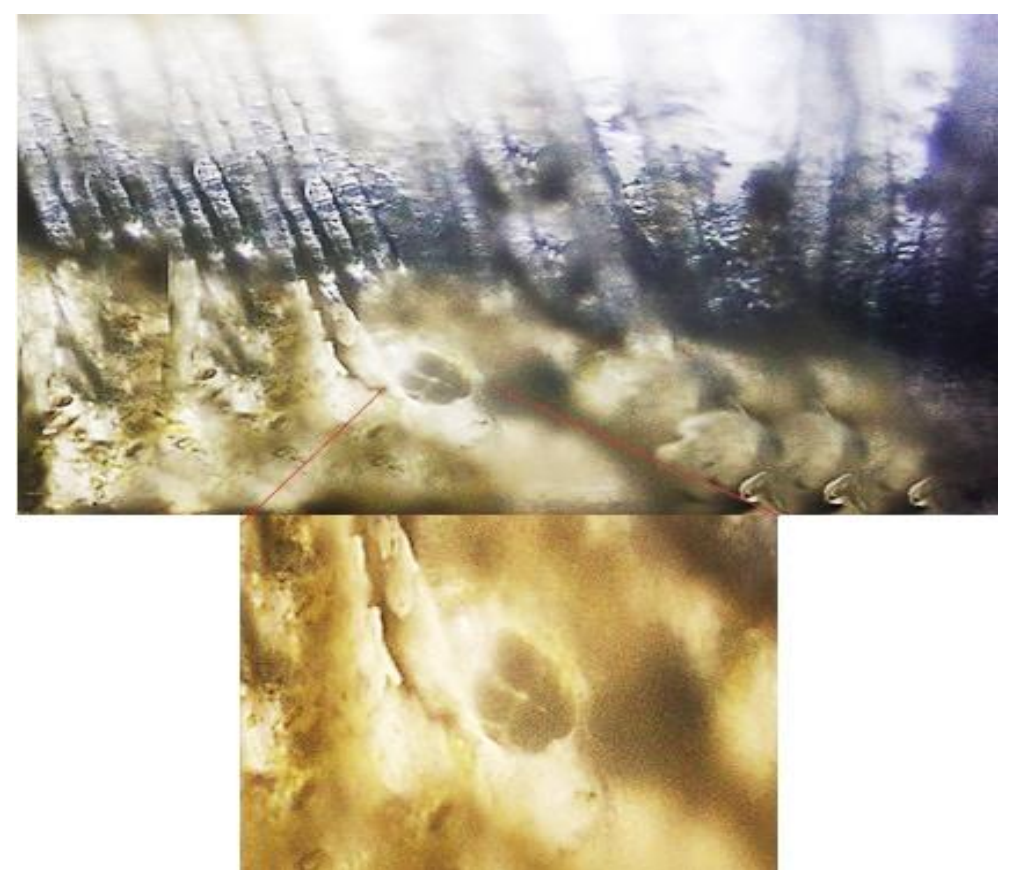

Fig. 12 Showing fresh mount of gill tissue infested with Amyloodinium ocellatum (advanced stage of division of tomont stage).

\section{3- Occurrence of Amyloodiniumocellatum infection}

In the present study, out of the examined 1065 Dicentrarchuslabrax fish, 618 (58.02\%) were found to be infested with Amyloodiniumocellatum. The highest rate of infestation was recorded during spring season with Prevalence $(90.10 \%)$ while the lowest was during winter season with Prevalence $(30.76 \%)$.

As shown in table (2) \& Fig. 13. 
Table 2 Showed Prevalence and seasonal dynamics of infestation by Amyloodiniumocellatum of European Seabass Dicentrarchuslabrax. In 2015-2016.G: gills: Skin.

\begin{tabular}{|l|l|l|l|l|l|}
\hline Season & $\begin{array}{l}\text { No. of Fish } \\
\text { Examined }\end{array}$ & $\begin{array}{l}\text { No. of Fish } \\
\text { Infested }\end{array}$ & Prevalence \% & species & Infected organs \\
\hline Spring & 546 & 492 & $90.10 \%$ & Fry & G.S \\
\hline Summer & 222 & 75 & $33.78 \%$ & Fry & G.S \\
\hline Autumn & 219 & 108 & $49.32 \%$ & fingerling & G.S \\
\hline Winter & 78 & 24 & $30.77 \%$ & Adults & G \\
\hline Total & $\mathbf{1 0 6 5}$ & $\mathbf{6 1 8}$ & $\mathbf{5 8 . 0 2 \%}$ & & $<0.0001$ \\
\hline $\boldsymbol{\chi}_{\text {Calc. }}^{2}$ & $\mathbf{7 3 . 5 5}$ & P-value & & \\
\hline
\end{tabular}

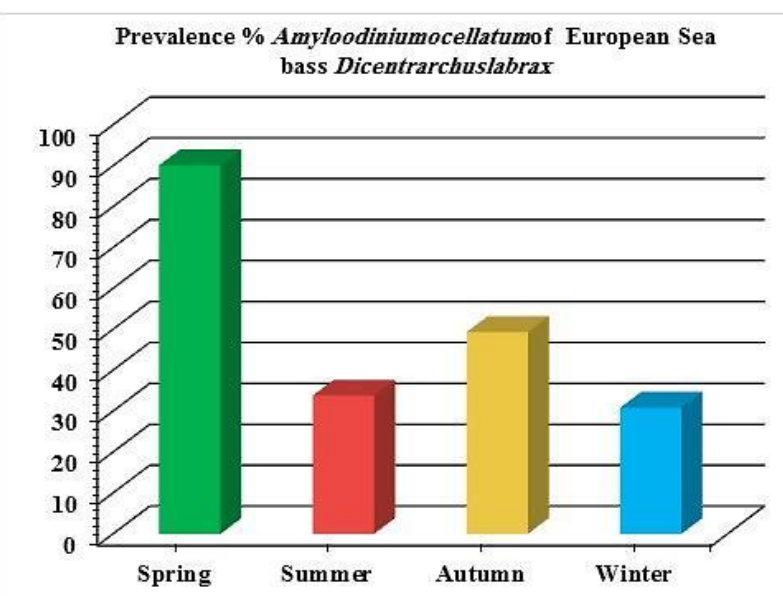

Fig. 13 Prevalence and seasonal dynamics of infestation by Amyloodiniumocellatum ofDicentrarchuslabrax.

4- It was necessary to study the Correlation among water quality parameters and Amyloodiniumocellatum infestation during prevalence period (table 3) \& Fig. $(14,15,16,17 \& 18)$ :

A- There was direct strong significant correlation between $\mathrm{pH}$ levels and parasitic infestation $(-.457, \mathrm{p}=0.043)$

B- Also, there was a significant correlation between Salinity levels and parasitic infestation $(473, \mathrm{p}=0.035)$.

$\mathrm{C}$ - There was a significant correlation between water temperature and parasitic infestation $(-0.165, \mathrm{p}=0.043)$

D- There was a weak significant correlation between ammonia levels and parasitic infestation $(0.057, \mathrm{p}=0.488)$.

Table 3 Correlation among water quality parameters and parasitic infestation during prevalence period of Amyloodinium ocellatum infection.

\begin{tabular}{|l|l|l|}
\hline Parameter & R & P-value \\
\hline Temperature & -0.165 & 0.488 \\
\hline Dissolved Oxygen & 0.009 & 0.97 \\
\hline pH & $-.457^{*}$ & 0.043 \\
\hline Salinity (ppt) & $.473^{*}$ & 0.035 \\
\hline Ammonia (ppm) & 0.057 & 0.81 \\
\hline
\end{tabular}

r; Pearson Correlation coefficient

* Correlation is significant at the 0.05 level (2-tailed).

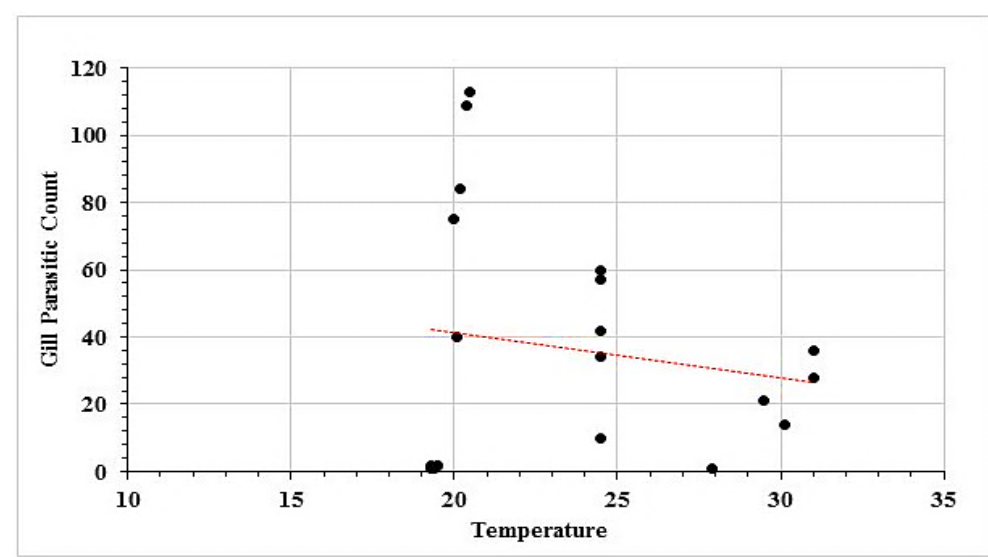

Fig. 14 Pearson Correlation between gill parasitic count and water temperature 


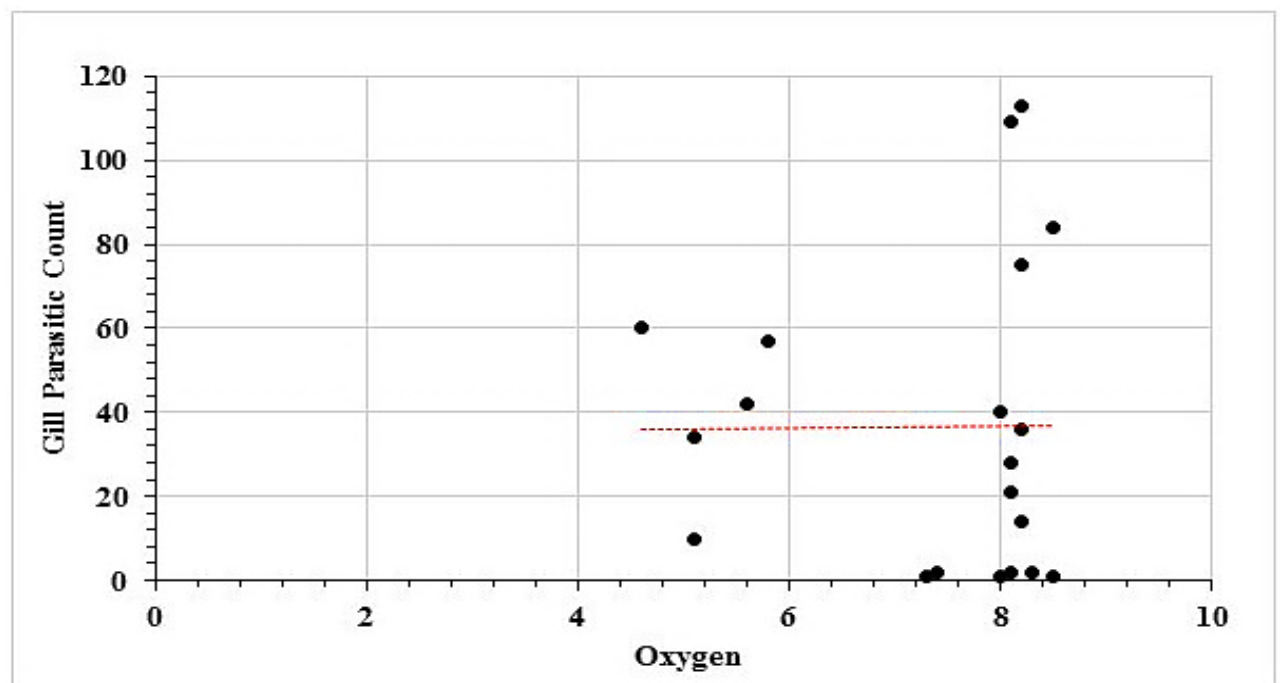

Fig. 15 Pearson Correlation between gill parasitic count and water Oxygen Level

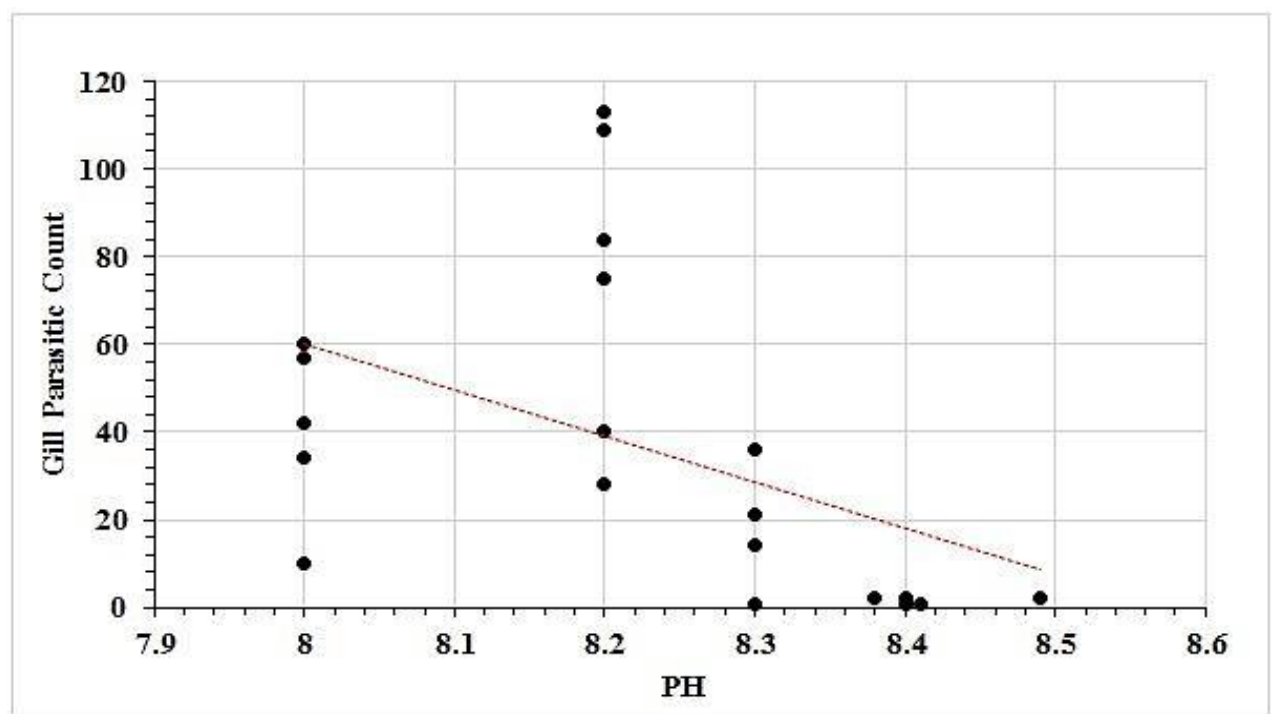

Fig. 16 Pearson Correlation between gill parasitic count and water PH

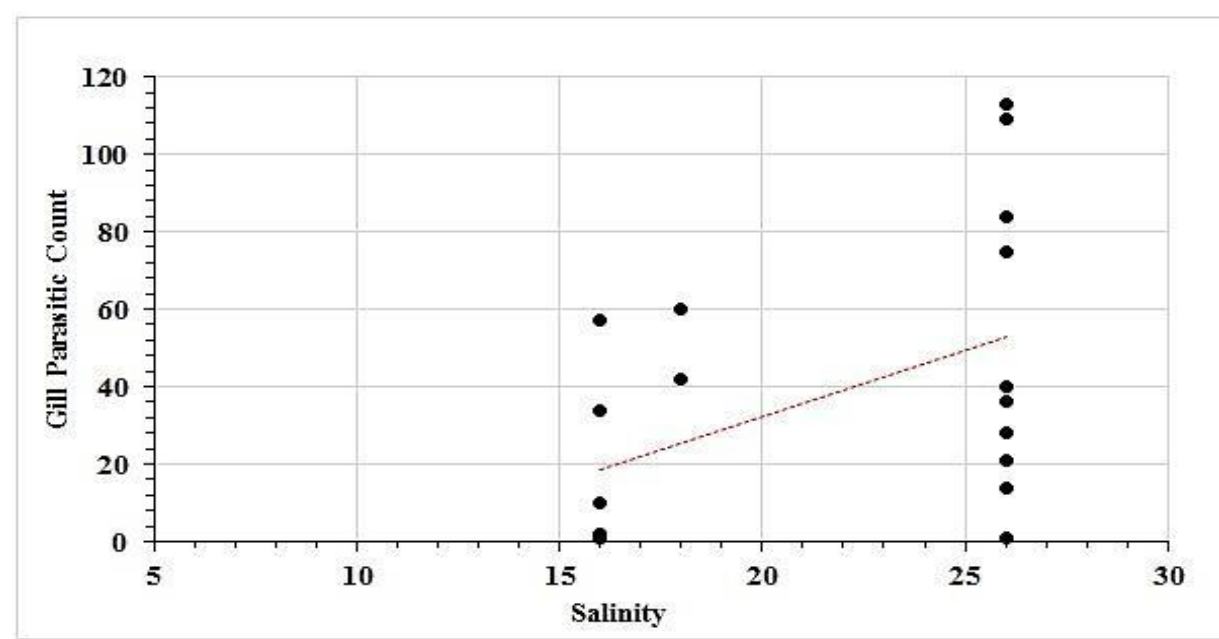

Fig. 17 Pearson Correlation between gill parasitic water salinity 


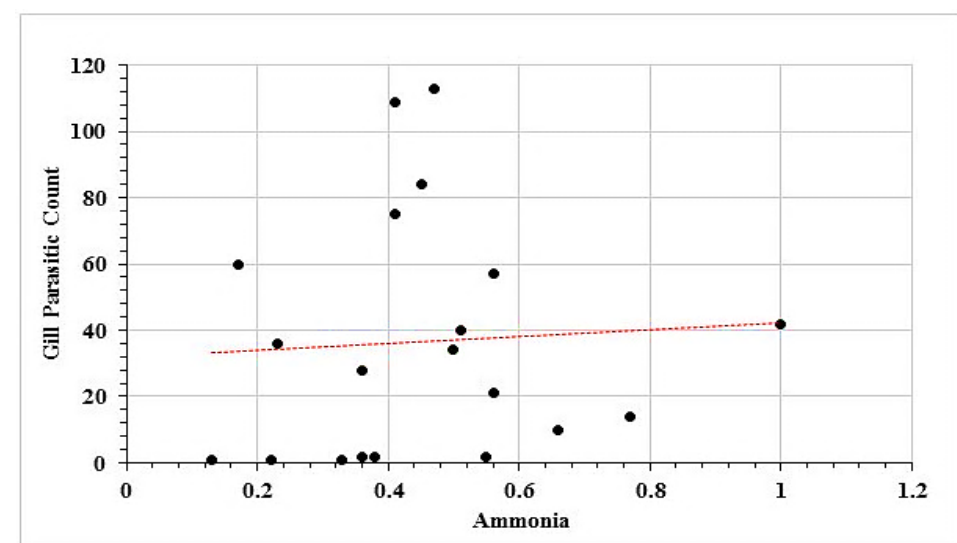

Fig. 18 Pearson Correlation between gill parasitic count and water ammonia level

\section{5- Histopathological alterations}

Infestations of $D$. labrax by Amyloodiniumocellatum are usually involve the gill as the primary site of infestation may also the skin and eyes. Thus there were histopathological changes ranged between mild infestations by low number of trophonts per gill filament and cause little alteration. But, heavy infestations by high number of trophonts can cause serious gill hyperplasia, inflammation, hemorrhage, and necrosis. As shown in (Figures 19,20\& 25).

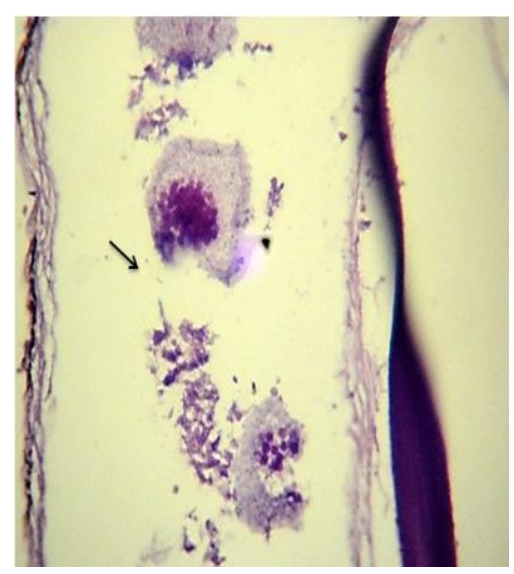

Fig. 19 showing Amyloodiniumocellatumtrophont (Arrowhead) surrounded with tissue debri underneath a scale $\mathrm{H} \& \mathrm{E}$ X100

Trophonts were also seen inside gill arch and tissues. Concerning the mild pathological changes, Amyloodiniumocellatumtrophont was attached to the skin and causing moderate hyperplasia and desquamation of the covering epithelium. (Figure 23\&26) on the other hand, several histpathological changes were seen in several forms as follow:Amyloodiniumocellatumtrophonts causing severe hyperplasia in the gill epithelia and fusion of the secondary gill lamell Fig.( $21 \& 22)$.Amyloodiniumocellatumtrophont and its attachment site to the destructed secondary gill lamella Fig.(24 \&27).

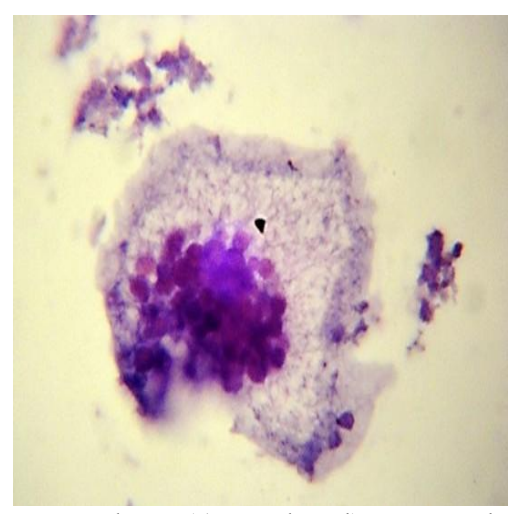

Fig. 20 showing Amyloodiniumocellatumtrophont (Arrowhead) surrounded with tissue debri underneath a scale $\mathrm{H} \& \mathrm{E}$ X400 


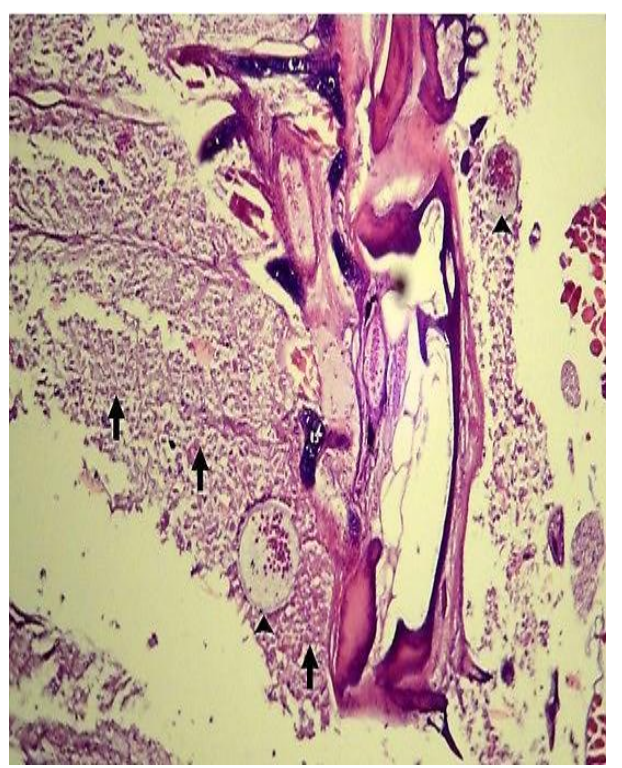

Fig. 21 Showing Amyloodiniumocellatumtrophonts (Arrowheads) causing severe hyperplasia in the gill epithelia and fusion of the secondary gill lamella (Arrow). H\&E X100.

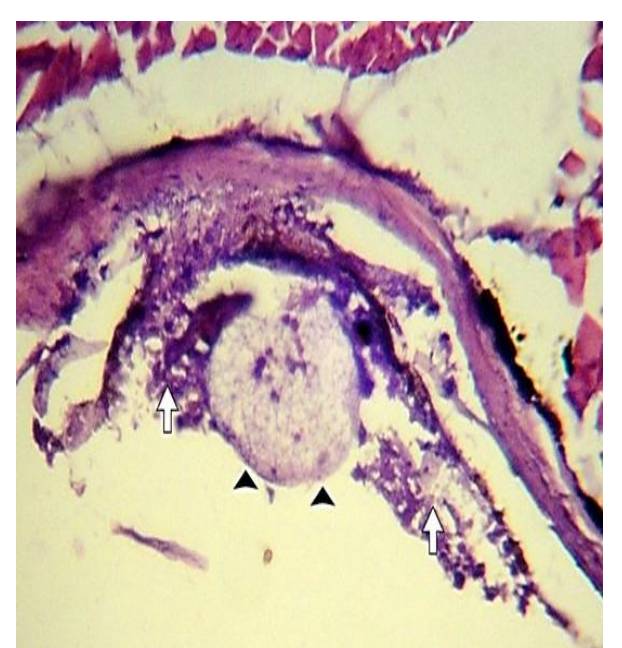

Fig. 22 High power of the previous figure showing Amyloodiniumocellatumtrophont (Arrowheads) with the severe hyperplasia and fusion of the secondary gill lamella (Arrows). H\&E X400.

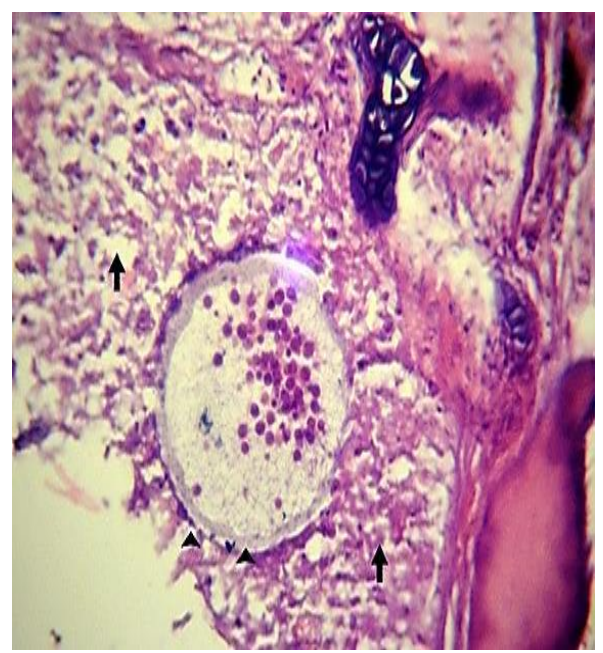

Fig. 23 Showing Amyloodiniumocellatumtrophont (Arrowheads) attached to the skin causing moderate hyperplasia and desquamation of the covering epithelium (Arrows). H\&E X400 


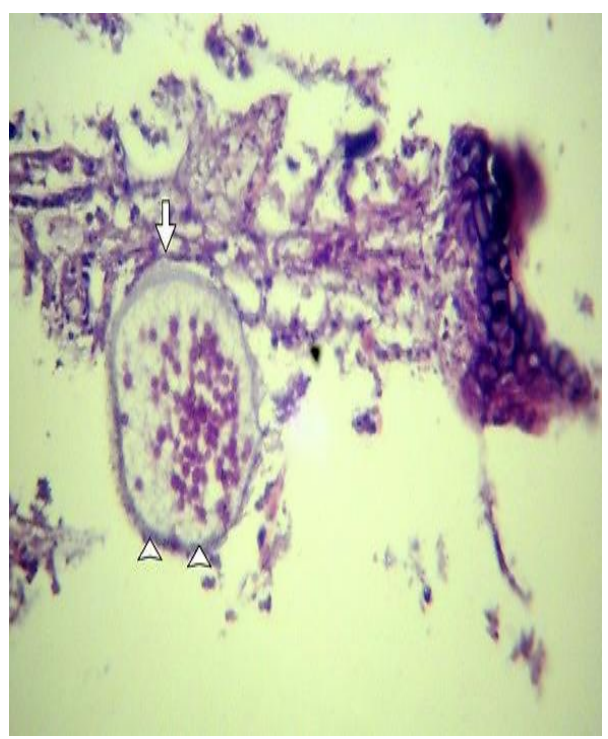

Fig. 24 Showing Amyloodiniumocellatumtrophont (Arrowheads) and its attachment site to the destructed secondary gill lamella (Arrow). H\&E X400.

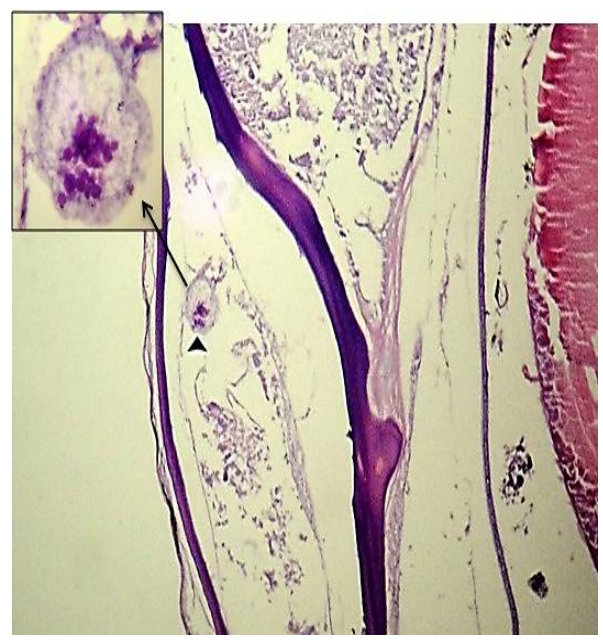

Fig. 25 Showing Amyloodiniumocellatumtrophont (Arrowhead) surrounded with tissue debri underneath a scale; Inset: high power of the A. ocellatumtrophont .H\&E X100, (inset, X1000).

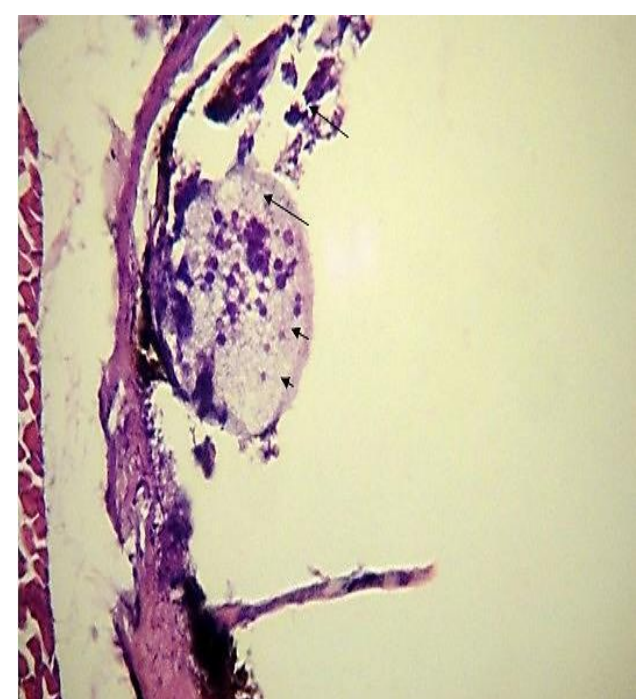

Fig. 26 Showing Amyloodiniumocellatumtrophont (Arrowheads) attached to the skin causing hyperplasia and desquamation of the covering epithelium (Arrows). H\&E X400. 


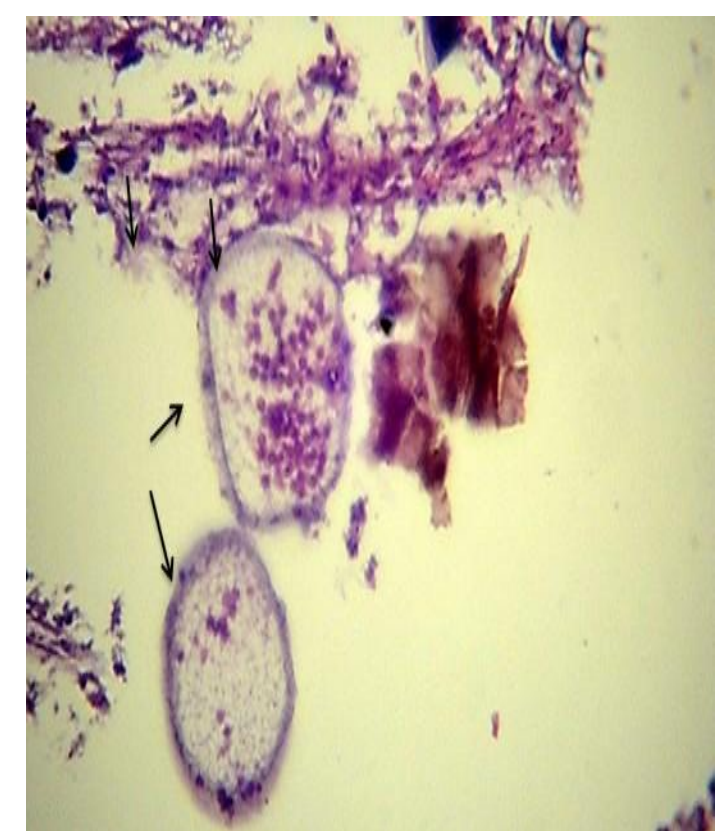

Fig. 27 Showing Amyloodiniumocellatumtrophont (Arrowheads) and its attachment site to the destructed secondary gill lamella (Arrow). H\&E X400.

\section{6- Treatment trials for Amyloodiniosis Results}

\section{A- Clinical signs before and after treatment Statistical Analysis:}

$>$ Before treatment the infected fish showed signs of distress loss of appetite flashing behavior mass mortality accumulation at water surface. Microscopic examination of skin and gill filament showed presence of tomont stage dark-brown in color mechanically dislodged between gill filaments.

$>$ After treatment feed consumption returned to a normal rate fishes in two treated groups resumed feeding from second day of commencement of treatment. Fish stopped dying increase vitality and trophont count decreased significally following treatment.

$>$ Effects of treatments on detachment of the trophonts and recovery of fish were studied the detachment of trophonts and its numbers were assessed by examining the gill filament skin and fin swab from the fish after treatment as in table (5). The final mean of mortality percentage i $\mathrm{n}$ each treated group was calculated on termination of treatment, as in table (4).

Table 4 Showing the final mean of mortality percentage i n each treated group that was calculated on termination of treatment.

\begin{tabular}{|l|c|c|c|c|c|c|c|}
\hline \multicolumn{1}{|c|}{$\begin{array}{c}\text { Parameter } \\
\text { Group }\end{array}$} & $\begin{array}{c}\text { Total } \\
\text { No }\end{array}$ & $\begin{array}{c}\text { mean } \\
\text { length } \\
(\mathrm{cm})\end{array}$ & $\begin{array}{c}\text { mean } \\
\text { weight } \\
(\mathrm{gm})\end{array}$ & Dose & $\begin{array}{c}\text { duration of } \\
\text { exposure }\end{array}$ & $\begin{array}{c}\text { Mean No } \\
\text { of } \\
\text { Mortality }\end{array}$ & $\begin{array}{c}\text { Mean \% } \\
\text { Mortality }\end{array}$ \\
\hline G1 control (-) & 30 & 6.98 & 7.43 & - & - & 0 & $0 \%$ \\
\hline G2 control (+) & 30 & 7.68 & 7.77 & - & - & 1 & $3.33 \%$ \\
\hline G3 Treated & 30 & 7.31 & 5.13 & $100 \mathrm{PPm}$ & $30 \mathrm{~min}$ & 1 & $3.33 \%$ \\
\hline G4 Treated & 30 & 8.05 & 6.33 & $200 \mathrm{PPm}$ & $30 \mathrm{~min}$ & 0 & $0 \%$ \\
\hline & 30 & 6.98 & 7.43 & - & - & 0 & $0 \%$ \\
\hline G1 control (-) & 30 & 7.68 & 7.77 & - & - & 3 & $10 \%$ \\
\hline G2 control (+) & 30 & \multicolumn{7}{|c|}{ Second Week } & & $0 \%$ \\
\hline G3 Treated & 30 & 7.31 & 5.13 & $100 \mathrm{PPm}$ & $30 \mathrm{~min}$ & 0 & $0 \%$ \\
\hline G4 Treated & 30 & 8.05 & 6.33 & $200 \mathrm{PPm}$ & $30 \mathrm{~min}$ & 0 & 0 \\
\hline
\end{tabular}


As shown in table (4 and 5), the mortality rate was decreased in the treated groups G1 G2 to become none in the second week. Also, the intensity of infection was decreased in the treated groups where skin smear and gill smear shown decreased no of Amyloodinium than the non-treated group.

Table 5 Showing Effects of treatments on detachment of the trophonts and recovery of fish.

\begin{tabular}{|c|c|c|c|c|c|c|c|c|}
\hline \multicolumn{9}{|c|}{ First Week } \\
\hline \multirow{2}{*}{$\begin{array}{l}\text { Parameter } \\
\text { Group }\end{array}$} & \multirow{2}{*}{$\begin{array}{c}\text { mean } \\
\text { length } \\
(\mathrm{cm})\end{array}$} & \multirow{2}{*}{$\begin{array}{c}\text { mean } \\
\text { weight } \\
(\mathrm{gm})\end{array}$} & \multirow{2}{*}{$\begin{array}{c}\text { Total } \\
\text { No }\end{array}$} & \multirow{2}{*}{ Dose } & \multirow{2}{*}{$\begin{array}{c}\text { duration } \\
\text { of } \\
\text { exposure }\end{array}$} & \multicolumn{2}{|c|}{$\begin{array}{l}\text { Mean Intesity } \\
\text { of Infection }\end{array}$} & \multirow[b]{2}{*}{$\begin{array}{c}\text { prevelance } \\
\%\end{array}$} \\
\hline & & & & & & $\begin{array}{l}\text { skin } \\
\text { smear }\end{array}$ & $\begin{array}{l}\text { Gill } \\
\text { smear }\end{array}$ & \\
\hline $\begin{array}{l}\text { G1 control (-) } \\
\text { apparently } \\
\text { healthy }\end{array}$ & 6.98 & 7.43 & 30 & - & - & 0 & 0 & $0 \%$ \\
\hline $\begin{array}{l}\text { G2 control } \\
(+) \text { infested }\end{array}$ & 7.68 & 7.77 & 30 & - & - & $12 / \mathrm{F}$ & $15 / F$ & $90.00 \%$ \\
\hline G3 Treated & 7.31 & 5.13 & 30 & 100 PPm & $30 \mathrm{~min}$ & $6 / \mathrm{F}$ & $10 / \mathrm{F}$ & $53.33 \%$ \\
\hline G4 Treated & 8.05 & 6.33 & 30 & 200 PPm & $30 \mathrm{~min}$ & $3 / \mathrm{F}$ & $10 / \mathrm{F}$ & $43 \%$ \\
\hline \multicolumn{9}{|c|}{ Second Week } \\
\hline G1 control (-) & 6.98 & 7.43 & 30 & - & 一 & 0 & 0 & $0 \%$ \\
\hline G2 control (+) & 7.68 & 7.77 & 30 & - & 一 & $10 / \mathrm{F}$ & $18 / \mathrm{F}$ & $93 \%$ \\
\hline G3 Treated & 7.31 & 5.13 & 30 & $100 \mathrm{PPm}$ & $30 \mathrm{~min}$ & $3 / F$ & $5 / F$ & $27 \%$ \\
\hline G4 Treated & 8.05 & 6.33 & 30 & $200 \mathrm{PPm}$ & $30 \mathrm{~min}$ & $2 / \mathrm{F}$ & $4 / F$ & $20 \%$ \\
\hline
\end{tabular}

Therefore, the prevalence rate was lower in the treated groups than non-treated. It was cleared that, this treatment with was more effective and excellent. It was confirmed through lower mortality rate and 0 percent prevalence rate.

Table 6 Comparison of Mortality number and percentage among treated groups no. (\%) after (30 min.) treatment (.G: group W: week).

\begin{tabular}{|c|c|c|}
\hline Groups & W1 & W2 \\
\hline Control -Ve(G1) & $0(0 \%)^{a}$ & $\mathbf{0}(0 \%)^{b}$ \\
\hline Control + Ve(G2) & $1(3.33 \%)^{a}$ & $3(10.0 \%)^{a}$ \\
\hline 100 ppm (G3) & $1(3.33 \%)^{\mathrm{a}}$ & $0(0 \%)^{b}$ \\
\hline 200 ppm (G4) & $0(0 \%)^{a}$ & $\mathbf{0}(\mathbf{0 \%})^{\mathrm{b}}$ \\
\hline
\end{tabular}

Percents within the same column sharing the same subscript are not significantly different at $\mathrm{p}<0.05$ in the twosided test Z-test. Tests are adjusted for all pairwise comparisons using the Bonferroni correction.

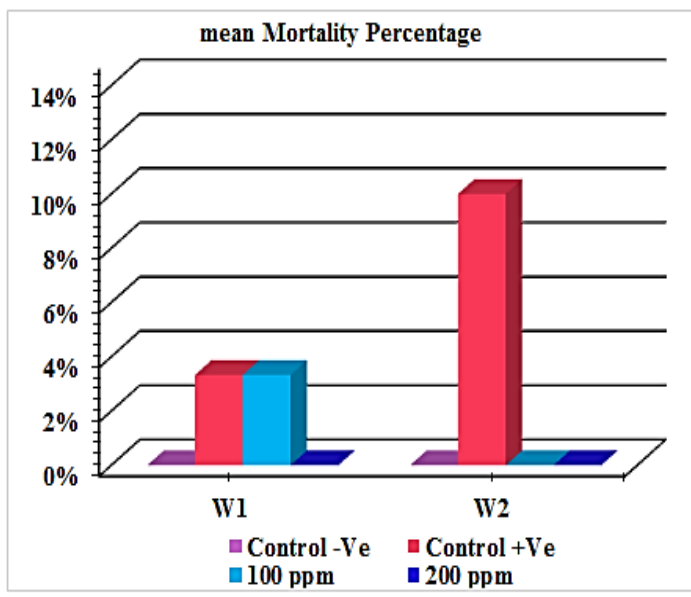

Fig. 28 Comparison of the mean Mortality number No. and percentage (\%) among treated groups after (30 min.) treatment. 
Table 7 Comparison of skin smear parasitic count among treated groups after (30 min.) treatment (G: group W: week).

\begin{tabular}{|l|l|l|}
\hline & W1 & W2 \\
\hline Control -Ve(G1) & - & - \\
\hline Control +Ve(G2) & $12 \pm 1.07^{\mathrm{a}}$ & $10 \pm 0.91^{\mathrm{a}}$ \\
\hline $100 \mathrm{ppm}(\mathrm{G3})$ & $6 \pm 1.11^{\mathrm{b}}$ & $3 \pm 0.83^{\mathrm{b}}$ \\
\hline $200 \mathrm{ppm}(\mathrm{G4})$ & $3 \pm 1.03^{\mathrm{c}}$ & $2 \pm 0.97^{\mathbf{b}}$ \\
\hline
\end{tabular}

Means within the same column carrying different superscripts are sig. different at $\mathrm{P}<0.05$ based on Tukey's Honestly Significant Difference (Tukey's HSD).

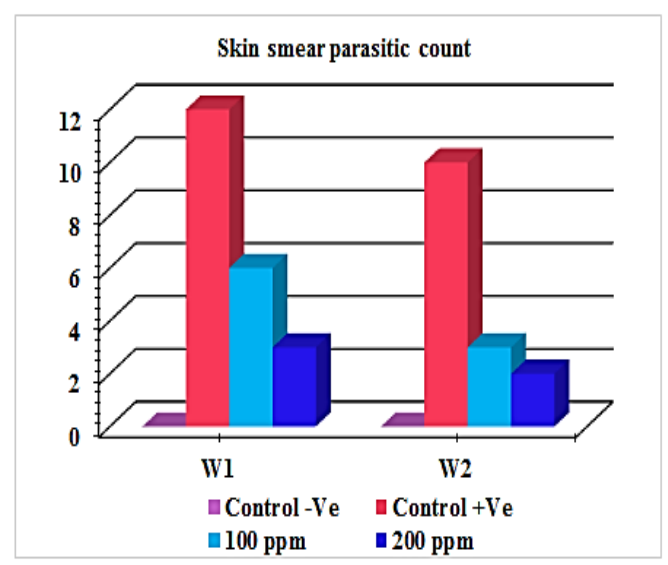

Fig. 29 Comparison of skin smear parasitic count among treated groups after (30 min.) treatment.

Table 8 Comparison of gill smear parasitic count among treated groups after (30 min.) treatment. (G: group W:

\begin{tabular}{|c|c|c|}
\hline & W1 & W2 \\
\hline Control-Ve(G1) & - & - \\
\hline Control + Ve(G2) & $15 \pm 0.74^{\mathrm{a}}$ & $18 \pm 0.93^{\mathrm{a}}$ \\
\hline 100 ppm (G3) & $10 \pm 1.01^{b}$ & $5 \pm 0.93^{b}$ \\
\hline 200 ppm(G4) & $10 \pm 0.93^{b}$ & $4 \pm 0.93^{b}$ \\
\hline
\end{tabular}

Means within the same column carrying different superscripts are sig. different at $\mathrm{P}<0.05$ based on Tukey's Honestly Significant Difference (Tukey's HSD).

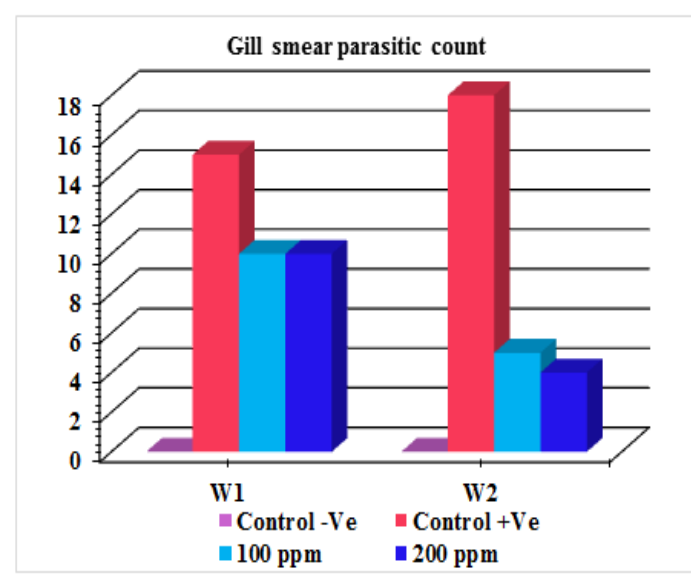

Fig. 30 Comparison of gill smear parasitic count among treated groups after (30 min.) treatment.

Table 9 Comparison of prevalence \% among treated groups after (30 min.) treatment (G: group W: week).

\begin{tabular}{|l|l|l|}
\hline & W1 & W2 \\
\hline Control -Ve(G1) & $0(0.0 \%)$ & $0(0.0 \%)$ \\
\hline Control +Ve(G2) & $27(90.0 \%)^{\mathrm{a}}$ & $28(93.3 \%)^{\mathbf{a}}$ \\
\hline 100 ppm (G3) & $16(53.3 \%)^{\mathbf{b}}$ & $\mathbf{8}(26.7 \%)^{\mathbf{b}}$ \\
\hline 200 ppm (G4) & $13(43.3 \%)^{\mathbf{b}}$ & $\mathbf{6}^{\mathbf{b}}(20.0 \%)^{\mathbf{b}}$ \\
\hline
\end{tabular}


Percents within the same column not sharing the same subscript are significantly different at $p<0.05$ in the twosided test Z-test. Tests are adjusted for all pairwise comparisons using the Bonferroni correction.

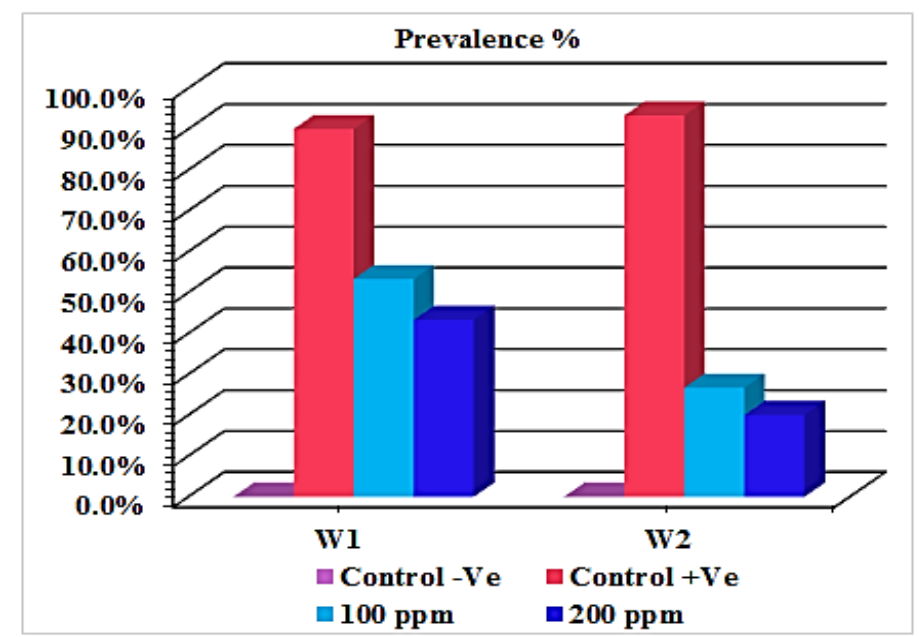

Fig. 31 Comparison of prevalence $\%$ among treated groups after (30 min.) treatment.

\section{B- It was cleared from the previous statistical analysis the following:}

$>$ There was no significance difference in mean mortality percentage in treated group with 100ppm and infested group in 1 st week \& 2 nd week. Also there was no significance difference in mean mortality percentage between treated groups $100 \mathrm{ppm} \& 200 \mathrm{ppm}$. $(1 \% \& 0 \%)$ respectively in $1^{\text {st }}$ week and in $2^{\text {nd }}$ week $(0 \% \& 0 \%)$ respectively. That revealed that no hazard on fish survival from used $200 \mathrm{ppm}$ as a higher dose in treatment design.

$>$ There was significance difference in prevalence rate percentage between non treated group and treated group 100ppm \& 200ppm $(90.0 \%, 53.3 \%$, \& 43.3\%) respectively, and $(93.3 \%, 26.7 \%, \& 20.0 \%)$ respectively in 2 nd week. That revealed that effect of hydrogen peroxide $20 \%$ lower the prevalence $\%$ in 1 st week which was down and decrease in 2 nd week.

It was cleared that there was no significance difference in prevalence rate percentage between the two doses that used in treatments design. in 1 st week \&2nd week.

$>$ It was concluded from the mean intensity of infection (skin smear parasitic count \& gill smear parasitic count that the load of infection in gill smear is higher than in skin smear18\&10 respectively. That means that the primary site of infection and the main target organ of amyloodinium ocellatum trophontis the gill tissues.

$>$ It was concluded that there was significance difference in skin smear parasitic count between treated groups \&non treated groups in 1 st \&2nd weeks. Also there was significance difference in skin smear parasitic count between treated groups $100 \mathrm{ppm} \& 200 \mathrm{ppm}(6 \& 3)$ respectively, in $1^{\text {st }}$ week while in $2^{\text {nd }}$ week there was no significance difference $(3 \& 2)$ respectively.

$>$ It was concluded that there was significance difference in gill smear parasitic count between treated groups \&non treated groups in $1^{\text {st }} \& 2^{\text {nd }}$ weeks. Also there was no significance difference in gill smear parasitic count between treated groups 100ppm \& 200ppm (10\&10) respectively, in 1st week also in 2nd week there was no significance difference $(5 \& 4)$ respectively.

$>$ The infested fishes were exposed to $100 \mathrm{ppm} \& 200 \mathrm{ppm}$ hydrogen peroxide $20 \%$ for thirty minutes. The control fish were examined and found to have a mean of $18 \pm 0.93$ trophonts per gill biopsy \& $10 \pm 0.91$ trophonts per skin smear. The fish that were to be treated with100ppm showed a mean of $10 \pm 1.01$ trophonts per gill biopsy in first week \& $6 \pm 1.11$ trophonts per skin smear. The fish were retreated with 100 ppm hydrogen peroxide for thirty minute for another 6 days and the count was down to $5 \pm 0.93$ trophonts per gill biopsy \& $3 \pm 0.83$ trophonts per skin smear. The fish were treated with another dose $200 \mathrm{ppm}$ hydrogen peroxide for thirty minute for 6 days. the fish that were to be treated with 200ppm showed a mean of $10 \pm 0.93$ trophonts per gill biopsy in first week \& $3 \pm 1.03$ trophonts per skin smear. The fish were retreated with 200 ppm hydrogen peroxide for thirty minute for another 6 days; the count was down to $4 \pm$ 0.93 trophonts per gill biopsy \& $2 \pm 0.97$ trophonts per skin smear. 


\section{Discussion}

(Eissa, 2002) reported that, by increasing intensification of fish production and lack of health management measures have led to many disease problems. About $80 \%$ of fish disease is parasitic especially in warm water fish. The ectoparasiticprotozoal diseases (gill and skin parasites) of fishes play an effective role in the economic losses of fish farms through mortality and/or decrease growth rate of fish especially in the highly intensified systems. (Pereira et al., 2010) Reported that among the most important ectoparasitic protozoa is Amyloodinium ocellatum, a dinoflagellate which causes one of the most serious diseases of warmwater marine aquaculture and the disease caused by this organism is commonly referred to as amyloodiniosisor marine velvet disease. (Lom\&Dikov, 1992) reported changes in fish behavior, with jerky movements, swimming at the water surface and decreased appetite. (Levy et al., 2007) suggested that, the first indication of an amyloodinium infection is dead or dying fish. Behavioral signs may include a decrease in or complete lack of feeding activity, flashing (rubbing against objects in the tank or on the bottom substrate) and coughing (back flushing water across the gills). The skin of heavily infected fish may have a dull gold or brown sheen. And also may reveal scale loss and patchy accumulation of mucus. (Levy et al., 2007) observed that, infected fish sometimes develop a white or brown coloration ("velvet") or cloudy appearance, if the primary site of infection is skin, which is most visible when viewed with indirect lighting such as a flashlight. Such fish may display signs of "flashing" or rubbing on tank walls, the substrate, or other structures in their environment. Again, feeding behavior likely will be poor and some fish may appear emaciated. Fish with Amyloodinium infection alone do not typically have ulcers, white spots, or fuzzy lesions, but the skin can seem "hazy" in appearance. If the infection is confined to the gill, the "velvet" appearance will not be present.

The present study showed that infested European seabass Dicentrarchuslabrax with Amyloodinium ocellatum appeared distressed, emaciated, and anorexic and showed flashing behavior. Also, there were gasping of air rapid gill movement and lying on the bottom. There was rapid and mass death of fish. The affected skin showed friable skin (velvet like appearance), darkened, excessive mucous secretions forming cloudy film of slime. Also, grossly focal erosion areas were seen on the operculum and caudal tail. (Schwarz \& Smith 2009) observed by Light microscopy of moribund and dead fry showed brownish or yellowish, round to oval-shaped trophonts attached to the body of the fish. The infestation on July resulted to a sudden mass mortality. Some trophonts might have completed its feeding stage and detached to become a tomont (Lom\&Dikov, 1992) mentioned that the method of diagnostic is the identification of the trophont in the skin and gills of infected fish, which can be done through microscope observation of these tissues. Trophonts are ovoid with 150-350 microns. Gills are first to be infected. In this study it was concluded that intensity of infection in gill tissues was higher than in skin tissues respectively. That indicates that primary site of infection and the main target organ of is gill tissues. Also that is confirmed from the histopathologcal diagnosis that revealed mild hyprerplasia in skin tissue while in gill tissue was severing. In this study Microscopic examination of skin and gills scrapings of examined D. labrax showed, round to oval small dark brown mucoid Amyloodenium ocellatum stage. Different developmental life stages of Amyloodinium ocellatum were seen in the gill and skin tissues as the two main inhabitant organs.

The first stage was trophonts with its root - like structure (Rhizoids). They showed distended appearance with the presence of feeding stage trophonts dark brown color lodged between the gill filaments. Also, dislodged trophonts were also observed between the skin and fin surface. In detached trophonts (feeding stage) the rhizoids root-like structure (that penetrates deep in to epithelium causing substantial damage to tissue at the attachment site)of the attached organelle was sometimes visible.

The second was tomont stage; trophont stage feeds for several days, detaches, retracts its rhizoids and becomes tomont. Tomonts (reproductive stage) in division were occasionally observed. The third was Dinospores, the tomont divides, producing Dinospores, were not observed as it is a free swimming stage in water. (Paperna, 1980; Johnson, (1990) mentioned that histologically, affected gills may appear hyperplastic (a proliferation of cells) and lamellar fusion may be evident. (Paperna, 1980) suggested that A. ocellatum is attached to and feeds from the host epithelial cell by means of rhizoids, which penetrate the host cell. The consumed cell gradually degenerates and collapses.

Damage to infected cells leads to focal erosion of the epithelium. Prolonged infection exhausts a generation of mucus cells and leads to accelerated desquamation. Proliferation of the epithelium causes obliteration of the gill lamellae, while the inner strata of the epithelium become spongious and in some cases undergo complete lysis. The histopathological diagnosis in present study revealed mild to severe histopathological changes. Severe hyperplasia was shown in the gill epithelia and fusion of the secondary gill lamella which was caused by Amyloodiniumocellatumtrophonts .Also Destructed secondary gill lamellawhich was caused by Amyloodinium ocellatum trophont attachment to gill tissue was observed. Amyloodinium ocellatum trophont was surrounded with tissue debri underneath a scale. Mild Hyperplasia and desquamation of the covering epithelium which was caused byattachment of Amyloodinium ocellatum trophont to the skin tissue. Environmental and seasonal dynamics of A.ocellatum infestation is documented by (Kuperman\&Matey 1999; 
Pereira et al 2010; Saraiva et al 2011). (Noga and Levy, 1995) reported that Infestations of the gilthead seabream by the gill parasite $A$. ocellatum may occur, particularly during summer. At the end of the growing season, when the water temperature increases within production ponds, the proliferation of the ectoparasite and the damage done to the developing fish can rapidly reach devastating proportions in terms of fish production.

In Portugal, (Menezes, 1994) reported several outbreaks of A. ocellatum in aquacultures from the central west, southwest and southern regions where the main fish species in production are gilthead seabream and seabass (Dicentracthuslabrax L.). Fish are usually introduced into production ponds in April, and captured in the following year, during summer. The growing period of gilthead seabream takes about 15 months. Infestations of the gilthead seabream by the gill parasite A. ocellatum may occur, particularly during summer. (Noga and Levy, 1995). Suggested that at the end of the growing season, when the water temperature increases within production ponds, the proliferation of the ectoparasite and the damage done to the developing fish can rapidly reach devastating proportions in terms of fish production. Low oxygen tension in the Salton Sea in the summer months may reinforce the negative impact of Amyloodinium ocellatum. The shortage of external oxygen, together with destructive alterations of the respiratory organs and distortion of epithelial tissues caused by parasitic trophonts may depress the respiratory functions of fish. The likelihood of death by suffocation is especially great for young fish heavily infected by parasitic trophonts. In this case, not only gas exchange in the gills but also cutaneous respiration as a main source of oxygen for these fish (Rombough \& Ure 1990) may have been reduced. Alterations in the water-salt balance processes in the damaged gills were also suspectedto occur (Wendelaar Bonga 1997). The developing immune system of such young fish may not be able to fight off infection successfully.

The present study to explain the occurrences per season of A. ocellatum in cultivated European seabass In, out of the examined 1065 Dicentrarchuslabrax fish, $618(58.02 \%)$ were found to be infested with Amyloodiniumocellatum. The highest rate of infestation was recorded during spring season with aprevalence $(90.10 \%)$ while the lowest was during winter season with aprevalence (30.76\%). (Khan and Thulin, 1991) mentioned that, environmental factors can strongly promote infestation of fish by external parasites In the Salton Sea, A. ocellatum infestation of young tilapias increased under unfavorable environmental conditions of the lake. The severity of fish infestation by A. ocellatum was determined by an interaction by the pathogen with abiotic variables, such as water temperature, salinity, oxygen concentration and nitrogen level. (Kuperman and Matey, 1999) suggested that the occurrence of A. ocellatum in fish gills is associated with specific variances in environmental variables such as temperature and salinity. A correlation study with environmental and biological factors as variables the occurrences of A. ocellatum in cultivated gilthead seabream) is conducted by (Pereira et al 2010). The study concludes that salinity is positively related with trophont occurrences. Dissolved oxygen, water temperature, $\mathrm{pH}$, and phytoplankton biomass have significant negative relationship with $A$. ocellatumtrophonts. (Pereira et al., 2010) is conducted the correlation study with environmental and biological factors as variables to explain the occurrences of $A$. ocellatumin cultivated gilthead seabream.

Salinity is positively related with trophont occurrences. Dissolved oxygen, water temperature and $\mathrm{pH}$, have significant negative relationship with A. ocellatum trophonts. (California Regional Water Quality Control Board 1994, J. Watts unpubl. data), found that, the parasitic adinoflagellate Amyloodinium ocellatum appears to be as an important factor affecting survival of fish populations in the Salton Sea. The parasite infestation of young tilapia increased under unfavorable conditions at the lake. The massive fish mortality events often reported at the Salton Sea may be the result of synergistic effects of parasite load and a complex set of environmental stressors. Salinity is the only environmental variable positively correlated with A. ocellatum trophonts, having an important role in parasite occurrences that is also supported, in part, by (Kuperman and Matey 1999), who pointed out that a combination of high water temperature and high salinity levels promoted heavy infestation by $A$. ocellatum. Thus, the present study attempts to correlate environmental factors with $A$. ocellatum, occurrences in cultivated European seabass. The present study concluded that there was direct strong significant correlation between $\mathrm{pH}$ levels and parasitic infestation. Also, there was astrong significant correlation between Salinity levels and parasitic infestation.

There was a weak significant correlation between ammonia levels and parasitic infestation. Also; there was a significant correlation between water temperature levels and parasitic infestation while there was no significant correlation between dissolved oxygen and A. ocellatum Occurrences. (Montgomery-Brock et al, 2001) reported that, Treatment with hydrogen peroxide to $75-150 \mathrm{mg} .1-1$ was effective in eliminating trophontes in Polydactylussexfilis. (Montgomery-Brock et al., 2000) described that the use of $35 \%$ hydrogen peroxide to treat mullet (Mugilcephalus) fry infested with Amyloodinium. Fish in a flow-through seawater system were treated once with $25 \mathrm{mg} / \mathrm{L}$ hydrogen peroxide for 30 minutes. Mortalities decreased from 200 to 1,000 fish per day to fewer than 10 per day within 3 days of treatment. The authors present data only for the first 4 days following treatment. Repeated treatments would be necessary under most culture conditions. While (Noga, 2010) mentioned that removing tomonts following treatment might be an important strategy when using this method. (Montgomery-Brock et al., 2000) described that some of these same people then prepared an 
experiment on Mullet (Mugilcephalus) fry. They first studied hydrogen peroxide's effect on healthy fish. Three groups of ten healthy fish were exposed to 75, 50, and 25 ppm hydrogen peroxide for thirty minutes. After 24 hours, the survival rates were 20,50 , and $70 \%$ respectively.

They then decided to test $25 \mathrm{ppm}$ hydrogen peroxide on a large larvae-rearing tank. This tank held 3000 liters of water and approximately three fish per liter. The facility had been experiencing 200-1000 deaths per day from Amyloodinium ocellatum for one week prior to the test in this vessel, while the standard daily mortality should have been $0.002 \%$. The fish were treated for 30 minutes with 25 ppm hydrogen peroxide. Within three days of the exposure, mortality dropped to less than 10 per day. (Montgomery-Brock et al., 2001) described that hydrogen peroxide is one of the newest ideas for treating Amyloodinium ocellatum and, one of the most interesting and promising as well. The first study he used 20 juvenile Pacific Threadfin (Polydactylussexfilis) suffering with an infection of Amyloodinium ocellatum. They were randomly divided into four open water tanks. One tank was the control and received no treatment. The control fish were examined and found to have a mean of $16.6 \pm 16.2$ trophonts per gill biopsy. The fish that were to be treated with varying levels of hydrogen peroxide were also examined and found to harbor a mean of $35.6 \pm 38.7$ trophonts per gill biopsy. Water flow to the three treatment tanks was stopped and they were dosed with hydrogen peroxide at concentrations of 75,150 , and $300 \mathrm{ppm}$. The fish were exposed for thirty minutes and then the water flow was returned to rid the tanks of the hydrogen peroxide. Within one hour of treatment, all the fish exposed to $300 \mathrm{ppm}$ hydrogen peroxide had perished, but the fish exposed to only 75 and $150 \mathrm{ppm}$ tolerated the treatment without any deaths. The surviving fish were examined immediately after treatment and found to harbor no more parasites. They were re-examined the following day. The treated fish were still infection free while the untreated fish were found to have an increase in the trophonts counted.

In the present study the infested fishes were exposed to $100 \mathrm{ppm} \& 200 \mathrm{ppm}$ hydrogen peroxide $20 \%$ for thirty minutes. The control infested fishes were examined and found to have a mean of $18 \pm 0.93$ trophonts per gill biopsy \& $10 \pm 0.91$ trophonts per skin smear. The fish that were to be treated with100ppm showed a mean of $10 \pm 1.01$ trophonts per gill biopsy in first week \& $6 \pm 1.11$ trophonts per skin smear. Whie in after six days, the count was down to $5 \pm 0.93$ trophonts per gill biopsy $\& 3 \pm 1.03$ trophonts per skin smear .The fishes were retreated with $200 \mathrm{ppm}$ hydrogen peroxide for thirty minute for another 6days. The fish that were to be treated with100ppm showed a mean of $10 \pm 0.93$ trophonts per gill biopsy in first week \& $3 \pm 1.03$ trophonts per skin smear. While in after six days, the count was down to $4 \pm 0.93$ trophonts per gill biopsy \& $2 \pm 0.97$ trophonts per skin smear. Fishes that exposed to $100 \mathrm{ppm} \& 200 \mathrm{ppm}$ of showed no mortalities recoreded.in the termination of experiment.

\section{Our results indicate that:}

\section{Conclusion}

The severity of infestation by A. ocellatum is determined by interaction of this pathogen with variable environmental stressors. Hydrogen peroxide proved its activity in experimental treatment trials it has the most potential for a mariculture-safe treatment option. Finally I recommend that infestations of European seabass by A. ocellatum can be avoided if a defined pattern of Quarantine, biosecurity and disinfection protocols are kept in mariculture facilities.

\section{Acknowledgement}

The authors would like to express their gratitude and appreciation to University of Mansoura in Egypt for giving them the opportunity to carry out this work, and I would like to especially thank Dr. Amr Fadel Hussein, Lecturer of fish disease, National Institute of Oceanography and Fisheries (N.I.O.F.) in AlexandriaEgypt, for his helping during the measurements, useful comments and assistance.

\section{References}

[1] Agius, C. and Roberts, R. J. (2003):Melanomacrophagecentres and their role in fish pathology, J. Fish Dis., 26: 499-509.

[2] Alvarez-Pellitero, P.( 2008 ): Diseases caused by flagellates. IN: Fish Diseases, Volume 1, Eiras, J.C., H. Segner,T. Wahli, and B.G. Kapoor (eds). Science Publishers:Enfield, NH, pp. 421-515.

[3] Washington, DC., ISBN: 0875530478, pp: 2-61. APHA,( 2005):. Standard Methods of Water and Wastewater. 21st Edn., American Public Health Association, Washington, DC., ISBN: 0875530478, pp: 2-61.

[4] California R egonal Water Quallty Control Board (1994): Water Quallty Control Plan Colorado River Basln-Region 7. State Water Resources Control Board.

[5] Eissa, I.A.M (2002): Parasitic fish diseases in Egypt, 1st. edition, pp: 52-53. D ar El-Nahdda El-Arabia publishing.

[6] Johnson, S.K. (1990): Recognition and control of diseases common to grow-out aquaculture of red drum. IN:Red Drum Aquaculture, G.W. Chamberlain, R.J. Miget, and M.G. Haby (eds). Texas A\&M University Sea Grant College Program, College Station, TX. pp. 113-130.

[7] Kuperman, B.I., Matey, V.E., (1999): Massive infestation by Amyloodiniumocellatum (Dinoflagellida) of fish in a highly saline lake, Salton Sea, California, USA. Dis. Aquat. Org. 39, 65-73.

[8] Khan, R.A., Thulin, J.,( 1991): Influence of pollution on parasites of aquatic animals. In:Baker, J.R., Muller, R. (Eds.), Advances in parasitology, Vol. 30. Academic Press, London, pp. 200-238. 
[9] Levy, M.G., M.F. Poore, A. Colorni, E.J. Noga, M.W. Vandersea, and R.W. Litaker. (2007 ): A highly specificPCR assay for detecting the fish ectoparasiteAmyloodiniumoscellatum. Diseases of Aquatic Organisms, 73:219-226.

[10] Lom, J. \&Dykova, I., (1992) : Protozoan parasites of fishes. In: Developments in Aquaculture and Fisheries Science, (Elsevier, Amsterdam), 26: 315 pp.

[11] Menezes, J., 1994 ):Doençasempeixescultivados no Estuário do Sado e o seucontrolo. Semináriosobrerecursoshaliêuticos, ambiente, aquacultura e qualidade do pescado da península de Setúbal, vol. 1. Institu toPortuguês de InvestigaçãoMarítima, Lisboa, pp. 175-186.

[12] Montgomery-Brock, M. D., Sylvester, J. Y., Tamaru, C. S. and Brock, J. (2000): Hydrogen peroxide treatment forAmyloodiniumsp. on mullet (Mugilcephalus) fry. Centerfor Tropical and Sub Tropical Aquaculture, Aqua. Tips Reg. Notes, 11(4): 4-6

[13] Montgomery-Brock, Dee, Vernon T Sato, James A Brock, \& Clyde S. Tamaru. (2001): The Application of Hydrogen Peroxide as a Treatment for the EctoparasiteAmyloodiniumocellatum (Brown 1931) on the Pacific Threadfin Polydactylussexifilis" Journal of the World Aquaculture Society, vol. 32, no. 2, pp. 250-254, June 2001.

[14] Noga, E.J. (2010 ): Fish Disease: Diagnosis and Treatment, Second Edition. Wiley-Blackwell: Ames, IA. pp. 13-48, 143-147, $375-420$.

[15] Noga, E.J. and M.G. Levy. (2006 ): PhyllumDinoflagellata. IN: Fish Diseases and Disorders, Volume I: Protozoan and Metazoan Infections, P.T.K. Woo (ed). CAB International: Oxford, UK. pp. 16-45.

[16] Noga E. J., Levy M. G., (1995): Dinoflagellate parasites of fish. In: Fish diseases I: Protozoan and metazoan infections. Vol. 1, Woo P. T. K. (ed), pp. 1-25, CAB International, Oxfordshire, Wallington, United Kingdom, 808 pp.

[17] Noga, E.J. (2010): Fish Disease: Diagnosis and Treatment, Second Edition. Wiley-Blackwell: Ames, IA. pp. 13-48, 143-147, $375-420$.

[18] Pereira J. C., Abrantes I., Martins I., Barata J., Frias P., Pereira I., (2010): Ecological and morphological features of Amyloodiniumocellatumoccurrences in cultivated gilthead seabreamSparusaurataL.: A case study. Aquaculture 310:289-297.

[19] Paperna, I., (1980) :Amyloodiniumocellatum (Brown 1931) (Dinoflagellida) infestations in cultured marine fish at Eliat. Red Sea: epizootiology and pathology. J. Fish Dis. 3,363-372.

[20] Rombough PJ. Ure D (1990): Partioning of oxygen uptake between cutaneous and branchial surfaces in larval and juvenile chinook salmon, Onchorchynchustschacvytscha. Physiol Zoo1 64:7 17-72.

[21] Schwarz M. H., Smith S. A., (2009) :Getting acquainted with Amyloodiniumocellatum.Commercial Fish and Shellfish Technology. Virginia Cooperative Extension. Fact Sheet, Pub. 600-200, Virgina, USA, 2 pp.

[22] WendelaarBonga SF (1997): The stress response in fish. Physiol Rev 77:591 -625.

[23] Zorrilla I, Chabrillón M, Arijo S, Díaz-Rosales P, Martínez - Manzanares E, Balebona MC, Moriñigo MA (2003a): Bacteriarecovered from diseased cultured gilthead sea bream (SparusaurataL.) in southwestern Spain. Aquaculture218:11-20. 